\title{
ANALYSIS OF THE CURRENT STATE OF SHELTERBELTS BY THE REMOTE SENSING DATA: RUSSIA, BELGOROD OBLAST
}

DOI: http://dx.doi.org/10.18509/GBP.2020.89

UDC: $630 * 26: 528.88(470)$

\author{
Anastasiya Narozhnyaya \\ Yury Chendev \\ Aleksander Solovyov \\ Maria Lebedeva \\ Olga Sablina \\ Belgorod National Research University, Russia
}

\begin{abstract}
Visual decoding of SPOT satellite images from the 1980s and images from the ArcGIS World Imaging platform (2017) has allowed define decreasing of the density of shelterbelts in the Belgorod oblast by $11 \%$ over 35 years. The areas of disturbed and abandoned tree stands that occupy about $16 \%$ of the existing shelterbelts length were marked. The reasons for the reduction of shelterbelts are their aging, lack of systematic care, destruction due to increasing the area of settlements. The opposite relationship between the length of disturbed and abandoned shelterbelts and the values of the hydrothermal coefficient (HTC) was revealed: in more arid climatic conditions of the Belgorod oblast (at the HTC lowering), the viability of shelterbelts decreases. On the southern slopes with steepness of more than $4^{\circ}$, the reduction in the length of shelterbelts at the decrease in the HTC occurs faster than on the slopes of other exposures. In the XX century, 10.3 thousand $\mathrm{km}$ of protective shelterbelts were created on the slopes of arable lands over $2^{\circ}(46 \%$ of the cultivated area), about $50 \%$ of them are deviated from the contour lines direction by more than $30^{\circ}$, which leads to soil erosion and the formation of scours, and then - ravines. Only $8.7 \%$ of contour (properly located) shelterbelts of the total length of protective shelterbelts on arable lands were revealed. According to additional calculations, for $35 \%$ of properly located protective shelterbelts, but without taking into account other important factors of their placement on the slopes, the potential soil loss exceeds the permissible values by the average of $41 \%$, accelerating the development of soil erosion. In order to protect the soil from erosion, new projects for creating shelterbelts must be developed and implemented, taking into account calculations of potential soil loss and relief features.
\end{abstract}

Keywords: shelterbelts, spatial-temporal dynamics of shelterbelts, inventory of shelterbelts, space images of high spatial resolution

\section{INTRODUCTION}

Long-term agricultural use of lands leads to various kinds of disturbances in the landscape system. To eliminate them and maintain high productivity of lands, adaptive landscape farming systems have been developed, in which agroforestry is one of the key events. The positive ecological role of shelterbelts is observed in the wide list of publications [1-7 et. al.].

Mass construction of shelterbelts in Russia began in the late 1940s - early 1950s, the works continued until the 1980s, and then the volumes decreased sharply, which was 
largely facilitated by the change of statehood and the absence of owners of these territories [8]. For today, the stand of shelterbelts is thinned out, and in some cases is completely eliminated $[9,10]$.

In view of the important role of shelterbelts in agricultural landscapes, the aim of this study is to analyze the spatial-temporal dynamics and the ecological state of shelterbelts in the old-developed agricultural region of Russia - the Belgorod oblast.

Such studies are required the providing by different-time cartographic material. Despite the considerable volume of sources on the use of satellite images in forestry, there is a shortage of studies analyzing the state of shelterbelts for regions.

\section{MATERIALS AND METHODS}

The study was conducted for the territory of the Belgorod oblast with the area of 27.1 thousand $\mathrm{km}^{2}$, the main part of which is located in the forest-steppe zone, and the SouthEastern part - in the steppe zone.

The study area corresponds to the south of the Central Russian Upland and it is an undulating plain, rising in the north and having weakly expressed slopes to the west southwest and east - southeast. More than $63.7 \%$ of the territory belongs to erosionally dangerous slopes with steepness of more than $2^{\circ}, 46 \%$ of which belong to arable lands (6.94 thousand $\mathrm{km}^{2}$ ) [11].

Since the Belgorod oblast is located in the Central Chernozem Region of Russia - in the area with favorable conditions for the development of agricultural production - the largest share in the land structure accounts for agricultural lands, the area of which is more than $70 \%$ of the total area. Forests are occupied $2,419 \mathrm{~km}^{2}(8.9 \%)$, and forest stands that are not part of the State forest fund, covered by $905 \mathrm{~km}^{2}$ (3.3\%), which is insufficient for the territory of forest - steppe. According to the authors [12] for forest-steppe environmental conditions, the total woodiness should be from 13 to $25 \%$.

A number of authors [13] point out the complexity or even impossibility of using remote sensing methods for shelterbelts decrypting due to their small width. Modern images of high and ultra-high spatial resolution can compete with aerial images in terms of object detail $[14,15]$ and in this case, visual interpretation allows carrying out more precise inventory and monitoring of forest stands [16].

In this study, the tools of the ArcGIS 10.2.2 software package were used. As cartographic materials the maps of land use scale of 1:10 000, at that $32 \%$ of them refers to the updating 1980-1981 (north-western part of the region) were applied. The remaining part is characterized by the state for 1955-1956. Retrospective analysis of satellite images (SPOT 1980s. etc.) also showed the lack of full coverage by them of the study area (covered 42\%). Therefore, the extrapolation of data for the 1950s and 1980s by reference key sites, evenly situated in the Belgorod oblast with the total area of $4410 \mathrm{~km}^{2}$ was conducted.

To study the current state of shelterbelts (2017), satellite images were used (the World Imagery Base Map with a spatial resolution of $0.6 \mathrm{~m} /$ pixels) in the ArcGIS package. These materials cover the entire territory of the Belgorod oblast. All spatial data was combined by using the WGS 1984 UTM Zone 37N projection coordinate system.

To create skeleton maps of the spatial-temporal dynamics of shelterbelts, on the first step the vectorization of shelterbelts on the land use maps S 1:10000 and their subdivision into antierosion (on slopes), field protective and roadside variants was carried out.

At the second step, these data were updated from satellite images by visual decoding. According to created maps, it was revealed that new shelterbelts were planted during the 
periods between surveys, some shelterbelts were completely disappeared from the turnover (Fig. 1A), and some of them have the broken, fragmented tree stand (Fig. 1B).
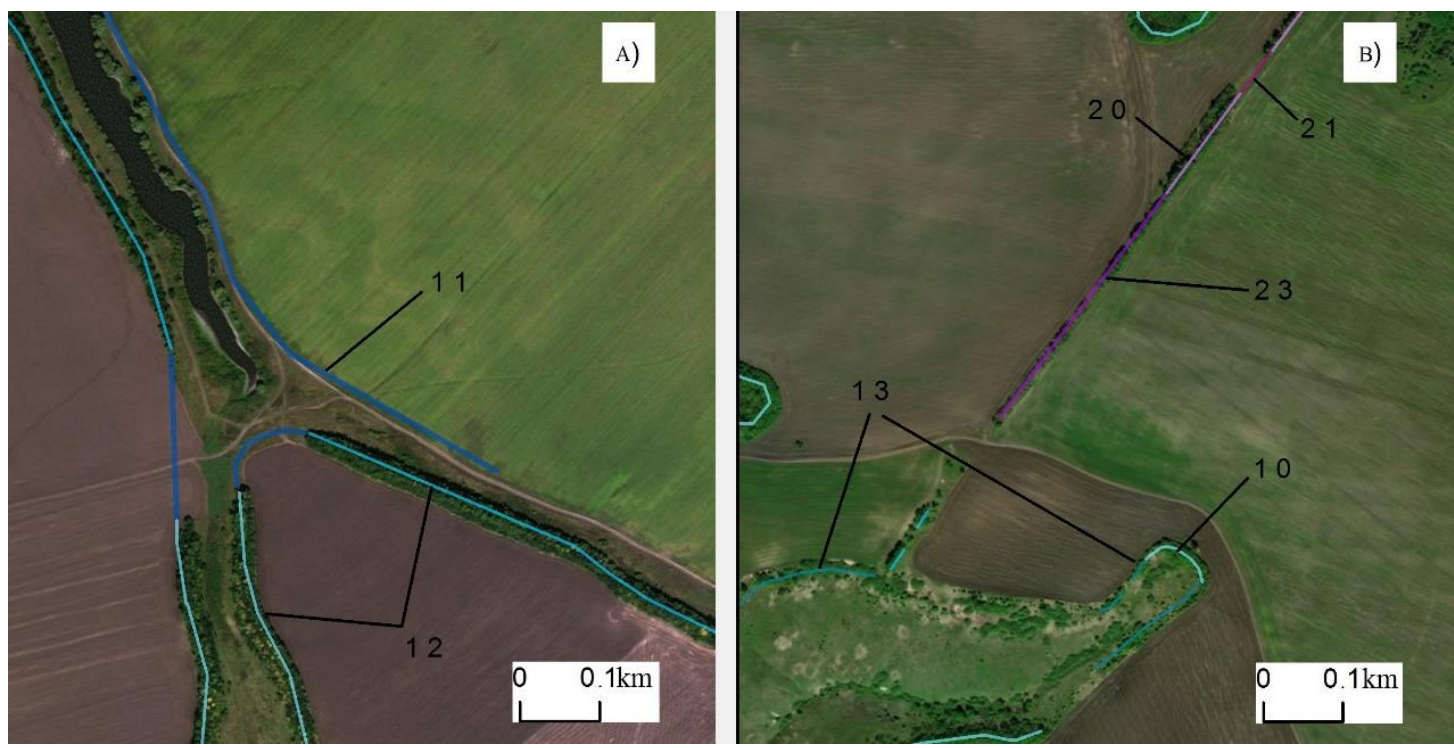

Figure 1. Updating maps of shelterbelts (fragment): A) 11 - antierosion disappeared shelterbelt; 12 - antierosion new shelterbelt; B) 10 - extant antierosion shelterbelt; 13 - disturbed antierosion shelterbelt; 20 - field protective shelterbelt; 21 - disappeared field protective shelterbelt;

23 - disturbed field protective shelterbelt (fragmented forest stand)

The corresponding indexes were assigned to all plots, herewith the shelterbelts selected along the maps were undergone by special processing to assign the attribute information to the disappeared or disturbed parts of shelterbelts (see Fig. 1).

To build the map of the density of shelterbelts the «lines density» tool with the search radius of $2.5 \mathrm{~km}$ was used. Digital terrain model and constructed morphometric maps based on this model were calculated on the basis of the topographic map S 1:100000 digitized by us earlier [11]. The tools «zonal statistics», «spatial statistics», «analysis», etc. were used for the aggregate analysis of thematic rasters and shelterbelts dynamics.

\section{RESULTS AND DISCUSSION}

Currently, shelterbelts are evenly distributed throughout the Belgorod oblast (Fig. 2). Areas with the shelterbelts density of less than $0.5 \mathrm{~km} / \mathrm{km}^{2}$ are more often confined to areas that are occupied by forests or settlements.

The average density of shelterbelts is $1.1 \mathrm{~km} / \mathrm{km}^{2}$. For reference areas that have different times map materials, we defined the length of shelterbelts and their density in different periods (table 1).

As can be seen from table 1, the density of antierosion shelterbelts was increased by 4.5 times in the study area since 1955 to 1980 , and the density of roadside shelterbelts was increased by 2 times. After the dissolution of the USSR, works on afforestation were stopped and only in the last decade they have resumed. In this regard, at the present stage, there is a decrease in the density of shelterbelts in comparison with the 1980s (table 1). Extrapolation of the established changes to the entire territory of the Belgorod oblast gave quite satisfactory results (table. 2). About this in particular the close values of the extrapolated percentage composition of all studied categories of shelterbelts for 2017, and the actual data obtained by analyzing modern satellite information are testified (table 2). 
The results of extrapolation over the entire territory of the study area show that the total length of shelterbelts from 1955 to 2017 could increase from 13.3 to 29.6 thousand $\mathrm{km}$ (table 2), however, in 1980, the length of shelterbelts could be higher than the current one by $12 \%$. Thus, the maximum density of shelterbelts was observed in the 1980s. The oldgrowth shelterbelts increasingly were affected to degradation - this was revealed for key areas with land use maps of the 1950s. Another important reason for the elimination is the reduction of shelterbelts with the increase the area of settlements.

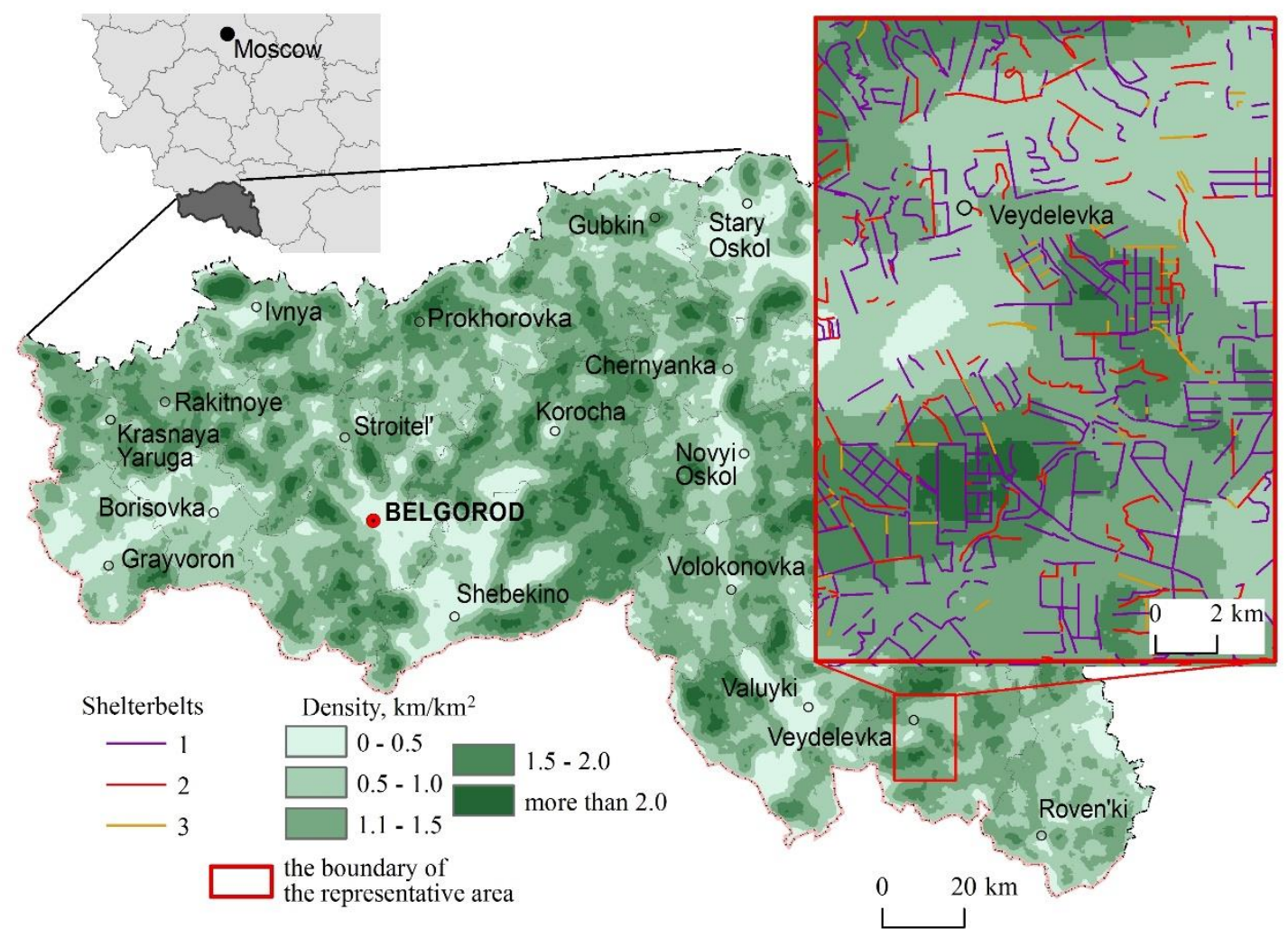

Figure 2. Shelterbelts in 2017 (1 - existing, 2- disappeared, 3- disturbed)

Table 1. Density of shelterbelts on reference key areas of the Belgorod oblast on different times map materials, $\mathrm{km} / \mathrm{km}^{2}$

\begin{tabular}{|l|c|c|c|c|c|}
\hline Type of shelterbelts & 1955 & 1980 & 2017 & $\begin{array}{c}\text { Difference } \\
1980-1955\end{array}$ & $\begin{array}{c}\text { Difference } \\
2017-1980\end{array}$ \\
\hline Antierosion & 0.13 & 0.59 & 0.54 & 0.46 & -0.05 \\
\hline Field protective & 0.23 & 0.47 & 0.45 & 0.24 & -0.02 \\
\hline Roadside & 0.13 & 0.16 & 0.15 & 0.03 & -0.01 \\
\hline Total & 0.49 & 1.22 & 1.14 & 0.73 & -0.08 \\
\hline
\end{tabular}

Table 2. Length of shelterbelts in the Belgorod oblast in different periods

\begin{tabular}{|c|c|c|c|c|}
\hline \multirow{2}{*}{$\begin{array}{c}\text { Type of } \\
\text { shelterbelts }\end{array}$} & \multicolumn{3}{|c|}{$\begin{array}{l}\text { Length in different periods, extrapolated on the } \\
\text { basis of correspondences according to table } 1\end{array}$} & \multirow{2}{*}{$\begin{array}{l}\text { Length in } 2017 \text { according to satellite } \\
\text { images, } \mathrm{km} / \% \text { from the entire length }\end{array}$} \\
\hline & $1955, \mathrm{~km}$ & $1980, \mathrm{~km}$ & $\begin{array}{l}2017, \mathrm{~km} / \% \\
\text { from the entire length }\end{array}$ & \\
\hline Antierosion & 3527 & 16009 & $14652 / 47$ & $14467 / 49$ \\
\hline Field protective & 6241 & 12753 & $12210 / 39$ & $10276 / 35$ \\
\hline Roadside & 3527 & 4341 & $4070 / 13$ & $4816 / 16$ \\
\hline Total & 13296 & 33103 & $30933 / 100$ & $29559 / 100$ \\
\hline
\end{tabular}


It should be noted that $3.7 \%$ of shelterbelts planted in the XX century, at the beginning of the XXI century, were disturbed to some extent, another $10.7 \%$ were completely disappeared, of which $44 \%$ are field protective shelterbelts and $38 \%$ are antierosion ones (Fig. 3).

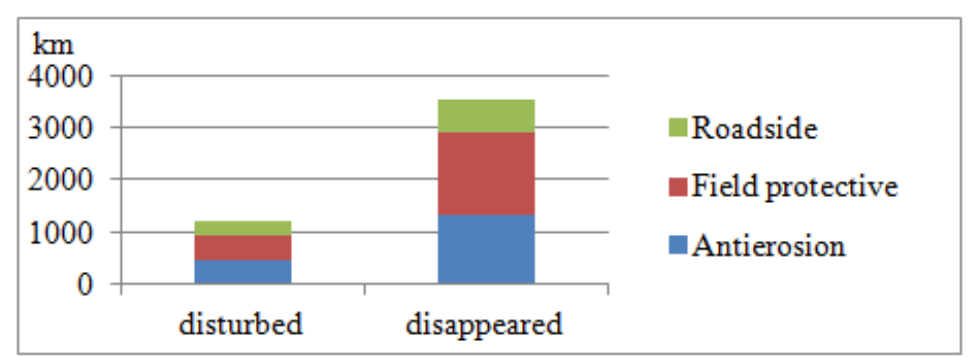

Figure 3. Disappeared and disturbed shelterbelts at the present period, identified by the analysis of different times materials

On average, in the territory of the Belgorod oblast, $0.96 \mathrm{~km}$ per $1000 \mathrm{~km}$ of total shelterbelts length planted before 1955 are eliminated from turnover annually. The mean annual rate of loss for younger shelterbelts that appeared in the period 1950-1980 is 0.23 $\mathrm{km} / 1000 \mathrm{~km}$. The loss of shelterbelts integrity and the formation of their fragmentation, according to our calculations, occur at the rate of $0.13 \mathrm{~km} /$ year per $1000 \mathrm{~km}$ of shelterbelts. On average, the degradated shelterbelts in the study area were oriented mainly from west to east, which may be related to the general direction of the slopes of the region.

The combined analysis of the slope steepness map and the map of shelterbelts shows that antierosion shelterbelts are more often disturbed or disappeared on slopes with a steepness of $4.7^{\circ}$, and field protective ones - on slopes with a steepness of $2.2^{\circ}$. The influence of slope exposure on the integrity violation of the shelterbelts was not revealed. But during the visual analysis of the skeleton maps it was noted that on the declivous slopes of the southern exposure the more expressive sparseness (fragmentation) of shelterbelts is more often occurred.

According to the combined analysis of modern satellite information and the slope steepness map, the antierosion shelterbelts are located on average on slopes with a steepness of $5.1 \pm 2.9^{\circ}$, field protective $-2.3 \pm 1.7^{\circ}$, roadside $-1.6 \pm 1.5^{\circ}$.

$47 \%(4783 \mathrm{~km})$ of field protective shelterbelts belong to slope lands (more than $2^{\circ}$ ). They require the contour placement across slopes, when orienting the shelterbelts along horizontals (the contour lines). However, about half of them deviate from the horizontals by more than $30^{\circ}$, which creates prerequisites for erosion processes development. In a number of cases on satellite images, the soil scours near not true located shelterbelts were found (Fig. 4).

As seen in Fig. 4A, in the central part of the shelterbelt, as the result of the runoff concentration, strengthening soil erosion formed a clearly visible scour, which is transformed into gully lower down the slope. In the other case (see Fig. 4B) was formed not a single scour, but a system of micro-stream network of scours.

The potential soil loss for the shelterbelts that were correctly designed on slopes relative to contour lines (parallel to them) was calculated. It was found that in $35 \%$ of cases, soil loss even on them exceeds the permissible values by the average of $41 \%$ (from 6 to $70 \%$ ). This indicates the insufficiency of shelterbelts, too large distances between them, and the incorrect location of the first shelterbelt in the upper part of the slope. 
Separate study on revealing of shelterbelts dynamics in different climatic conditions by using of the Selyaninov hydrothermal coefficient (HTC) has been executed.

When the values of the HTC decrease, i.e. in the more arid climate of the studied region, the length of field protective shelterbelts is reduced most of all (Fig. 5). Thus, the number of disappeared and disturbed shelterbelts increases from the north and north-west to the south and south-east in accordance with the decrease in the values of the HTC.
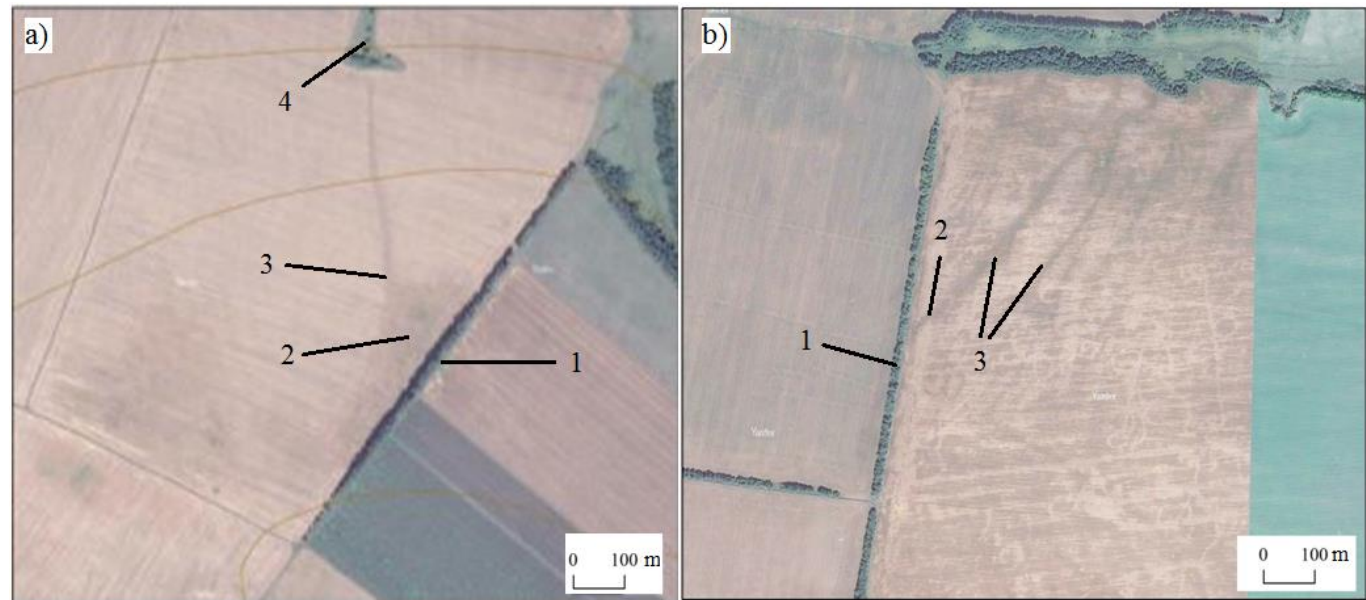

Figure 4. Adverse effect of not properly located shelterbelts: a) 1- shelterbelt with a deviation from the contour lines on $40^{\circ}$, 2-soil erosion zone, 3 - formation of scour; 4 - gully; b) 1- shelterbelt with a deviation from the horizontal on $80^{\circ}, 2$-soil erosion zone, 3 - formation of scours (explanation in the text)

The separate stage of the conducted study was to identify correlations between the observed degradation of shelterbelts and climatic features in the reference areas. As a result, for the 1955-2017 it was found that the change in the density of disappeared and disturbed shelterbelts is inversely proportional $(\mathrm{r}=-0.60)$ to the average value of the HTC (Fig. 5).

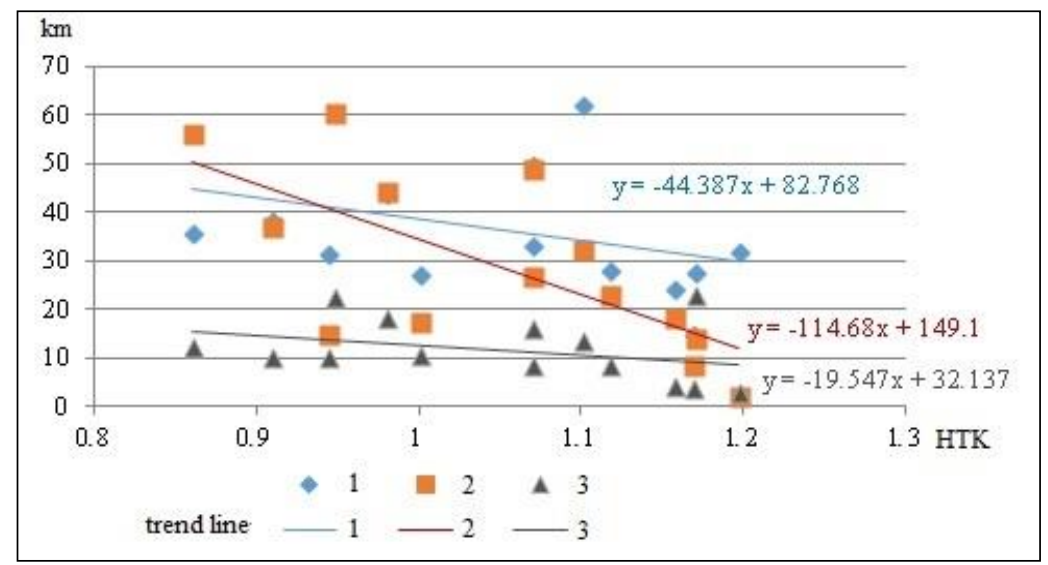

Figure 5. Dependence of the shelterbelts length decrease in time $(\mathrm{km})$ from the values of the HTC for key reference areas (1 - antierosion, 2 - field protective, 3-roadside)

\section{CONCLUSION}

As the result of the implementation of state programs, the length of shelterbelts in the Belgorod oblast has been increased from the middle of the XX century to the present time by more than 2 times, but $2525 \mathrm{~km}$ of shelterbelts that existed in the last century have been eliminated from the turnover, and another $1470 \mathrm{~km}$ have the partially broken 
(fragmented) forest stand. According to our calculations, about a quarter of straight shelterbelts on arable lands should be replaced with contour (along the relief horizontals) ones. Shelterbelts degradation is more revealed in the more arid parts of the Belgorod oblast, especially on the southern declivous slopes, which requires careful selection of the shelterbelts species composition and a general science-based adjustment of measures to optimization the shelterbelts fund.

\section{Acknowledgments}

This study was supported by the grant of Russian Science Foundation, project No. 19-1700056.

\section{REFERENCES}

[1] Liknes G.C., Perry, C.H., Meneguzzo D.M. Assessing tree cover in agricultural landscapes using high-resolution aerial imagery, Journal of Terrestrial Observation, 2(1), pp. 38-55, 2010.

[2] Meneguzzo D.M., Liknes G.C. \& Nelson M.D. Mapping trees outside forests using highresolution aerial imagery: a comparison of pixel-and object-based classification approaches, Environ. Monit. Assess, vol. 185(8), pp. 6261-6275, 2013.

[3] Chendev Y.G., Sauer T.J., Gennadiev A.N., et al. Accumulation of organic carbon in chernozems (Mollisols) under shelterbelts in Russia and the United States, Eurasian Soil Science, vol. 48 (1), pp. 43-53, 2015.

[4] Barabanov A.T. Transformation of the hydrological regime of agricultural lands, protective forest plantations, Zhivye i biokostnye sistemy, Russia, No 16, pp. 67-74, 2016.

[5] Zheng X., Zhu J., Xing Z. Assessment of the effects of shelterbelts on crop yields at the regional scale in Northeast China Author links open overlay panel, Agricultural Systems, vol. 143, pp. 49-60, 2016

[6] Erusalimskij V.I., Rozhkov V.A. The multifunctional role of protective forest plantations, Dokuchaev Soil Bulletin, Russia, No 88, pp. 121-137, 2017.

[7] Rempel A.C., Kulshreshtha S.N., Amichev B.Y. Costs and benefits of shelterbelts: A review of producers' perceptions and mind map analyses for Saskatchewan, Journal of Soil Science (Canada), vol. 97, No 3, pp. 341-352, 2017.

[8] Lomakin S.V. Taking into account the realities of a multi-layered economy in the conduct of land management of agricultural enterprises, Kadastrovoe i ekologo-landshaftnoe obespechenie zemleustrojstva v sovremennyh usloviyah, VGAU, Russia, pp. 158-162, 2018.

[9] Kulik K.N. Remote methods in agroforestry and environmental research, Collection of scientific papers of the international scientific and practical conference: Problems of rational use of natural resource complexes of dry territories, Russia, Volgograd, pp. 354-358, 2015.

[10] Simmons B.A., Marcos-Martinez R., Law E.A., Bryan B.A., Wilson K.A. Frequent policy uncertainty can negate the benefits of forest conservation policy, Environmental Science \& Policy, No 89, pp. 401-411, 2018.

[11] Narozhnyaya A.G., Buryak Zh.A. Morphometric analysis of digital elevation models of the Belgorod region at degrees of generalization, Belgorod State University Scientific Bulletin Natural sciences (Russia), No 25 (246), iss. 37, pp. 169-178, 2016.

[12] Baranov V.A. Optimization of agro-forest landscapes of the South-East of European Russia (for the 120th anniversary of the Dokuchaev expedition), Research in the field of natural Sciences, Russia, 2012, http://science.snauka.ru/2012/09/1538. 
[13] Heyman O., Gaston, G.G., Kimerling A.J., \& Campbell J.T. A per-segment approach to improving aspen mapping from high-resoultion remote sensing imagery, Journal of Forestry No 101(4), pp. 29-33, 2003.

[14] Zhirin V.M., Knyazeva S.V., Eidlina S.P. Estimation of Linkages Between Biometric Indexes of Forests and Pattern of Canopy Spaces on Super-high Resolution Satellite Images, Contemporary problems of ecology (Russia). No 3. pp. 163-177, 2018.

[15] Kulik K.N., Koshelev A.V. The methodical basis of the agroforest reclamation assesment of protective forest plantations by the data of remote monitoring, Forestry Engineering Journal, Russia, No 3, pp. 107-114, 2017.

[16] Piwowar J.M., Amichev B.Y. et al. Written Paper Saskatchewan shelterbelt inventory, Canadian journal of soil science, vol. 97 (3), pp. 433-438, 2016. 